\title{
密集住宅地における戸建住宅の風圧係数分布に関する実験的研究 \\ WIND PRESSURE COEFFICIENT DISTRIBUTION \\ OF DETACHED HOUSES IN A DENSE RESIDENTIAL BLOCK
}

\author{
谷口 景一朗*1, 赤 嶺 嘉彦*2 \\ Keiichiro TANIGUCHI and Yoshihiko AKAMINE
}

\begin{abstract}
In a dense residential block, the external airflow patterns around the site should be understood from the design stage to improve cross ventilation for enhancing occupant's comfort and saving energy. This study concluded the height and distance of the neighbor building have a significant contribution to the external airflow patterns. This conclusion was derived through surveying the blocks density of the main residential areas in Tokyo. Then, using a wind tunnel, we tested the influence of changing the height and distance of the neighbor building on the wind pressure coefficient under two scenarios; the typical residential models and the models with ventilation enhancing strategies.
\end{abstract}

\section{Keywords : Cross Ventilation, Wind Tunnel Test, Gross BCR, Height and Distance of Neighbor Buildings, Courtyard, Roof Monitor 通風，風洞実験，グロス建蔽率，隣棟高さ・距離，坪庭，越屋根}

\section{1. はじめに}

住宅において、夏期や中間期に冷房のみに頼らず、自然通風を行 うことで涼感を得て快適性を向上させる効果に対する居住者の期待 は省エネルギー・健康面双方の観点から大きい。しかし、高断熱・ 高気密化が進む近年の住宅では、設計段階から敷地周辺の外気流性 状を把握し適切な位置に開口部を設けなければ、通風利用による効 果は十分には見込めない。特に密集住宅地においては、効果的に風 圧力が作用する壁面あるいは屋根面を的確に見極めて開口部や通風 促進装置を提案することが重要であり、そのためには設計者が活用 しやすい風圧係数のデータベースを整備することが求められる。丸 田ら 1) は戸建住宅の外皮風圧係数のデータベース化を目指して、独 立建物を対象とした風洞実験を行い外皮風圧の基本性状の把握を行 っている。密集住宅地における通風促進装置の有効性に関する研究 は多く行われており、一例として村上ら 2) ${ }^{2}$ は実験用モデル住宅での 実測および風洞模型実験によって、天空を利用することで通風促進 に効果があることを示している。さらに、赤林ら $\left.{ }^{3}\right)$ は CFD を用い て戸建住宅の総合通風性能評価指標を提案し、建蔽率と平均通風量 比の関係を示すとともに、天空の通風促進効果を検証している。西 澤ら ${ }^{4)}$ は密集住宅地に建つ 2 階建て戸建住宅を対象とした風洞実験 を行い、密集地における通風性状を検討するとともに、ウィンドキ ヤッチャー・換気塔・屋根面開口等による通風促進効果を検証して いる。小林ら5) は勾配屋根に設けられた越屋根に着目し、風洞実験
により越屋根付設建物の風力換気特性を明らかにすることで、越屋 根を用いた住宅の風力換気量計算を可能としている。また滝澤ら 6 ) は、CFD を用いた事前検討から換気塔の性能を定量的に評価するた めのモデルを提案し、風洞実験および CFD により特に密集市街地 において換気塔が、通風・自然換気を活用する際の有効な設計手法 であることを示唆している。

一方で、密集住宅地においては隣棟の影響により設計者が入手可 能な最寄りのアメダス気象データの卓越風向と実際の敷地の卓越風 向が多くのケースで異なることが実測により明らかとなっている7） 佐藤ら 8) は、隣棟の規模や離隔距離による計画対象建物への風圧減 少の影響を風洞実験により明らかにしているが、隣棟の高さおよび 距離の違いによる対象建物の壁面あるいは屋根面の風圧係数のデー タベースはまだ十分ではない。

そこで、本研究ではまず 2 章で東京の主要な住宅地を対象とした 街区密度調查を行い、密集住宅地の建て込み状況（「グロス建蔽率」 と定義）の実態を把握する。把握したグロス建蔽率の実態をもとに 風洞実験で街区密度を再現し、3 章では街区密度および街区形状が 対象建物の壁面・屋根面に作用寸る風圧力に与える影響を、4 章で は、対象建物の妻面側もしくは平面側の隣棟高さおよび距離が変化 した場合に与える影響を検証する。5 章では、通風促進装置である 坪庭および越屋根について、前章と同様に隣棟の高さおよび距離が 変化した場合にも有効に作用するかを検証する。

\footnotetext{
*1 東京大学大学院工学系研究科建築学専攻 特任助教 - 修士 (工学)

*2 国土交通省国土技術政策総合研究所住宅研究部 主任研究官・博士 (工学)
}

Project Assist. Prof., Graduate School of Eng., The Univ. of Tokyo, M.Eng. Senior Researcher, Housing Dept., National Institute for Land and Infrastructure Management, Dr.Eng. 


\section{2. 街区密度調査}

東京 23 区のうち住宅面積が比較的大きい世田谷区と杉並区を対 象として、第 1 種および第 2 種低層住居専用地域の街区密度調查を 行った。調查方法は Fig.1 に示すように、まず各区の都市計画図か ら対象とする第 1 種および第 2 種低層住居専用地域を調べ、丁単位 の住所により世田谷区は 74 街区、杉並区は 78 街区に分割した。次 に、それぞれの街区について地理情報システム（GIS）の電子デー 夕に基づき、街区の建て込み状況を把握した。街区の建て込み状況 は、街区全体の面積 $\left(\mathrm{m}^{2}\right)$ に対する街区内に建つ各住宅の建築面積 の合計 $\left(\mathrm{m}^{2}\right)$ で示す。以下、これをグロス建蔽率（Gross BCR (Building Coverage Ratio))（\%）と記す。

$$
\text { グロス建蔽率 }(\%)=\frac{\text { 街区内の各住宅の建築面積の合計 }\left(\mathrm{m}^{2}\right)}{\text { 街区全体の面積 }\left(\mathrm{m}^{2}\right)} \times 100
$$

ここで定義したグロス建蔽率は、道路・公園・空地などすべてを 含む地域全体の面積を基準として算出するもので、一般的に用いら れる建物の敷地面積に対する建蔽率とは異なる。

世田谷区および杉並区のグロス建蔽率ごとの度数分布および累積 頻度を Fig. 2 に示す。杉並区の方が世田谷区よりも広範囲のグロス 建蔽率に街区が分布しているが、ほとんどの街区はグロス建蔽率 24 〜 $42 \%$ の範囲にあり、平均は両区ともに約 $33 \%$ 、標準偏差は世田谷 区が $4.6 \%$ 、杉並区が $6.8 \%$ であった。Fig. 3 にグロス建蔽率 $28 \%$ 、 $33 \% 、 43 \%$ の実在住宅地の例を示す。以上より、風洞実験で再現す る街区密度は、グロス建蔽率 $33 \%$ を基準とし、5\%刻みで $23 \% 、 28 \%$ 、 $33 \% 、 38 \% 、 43 \%$ の 5 種類とした。

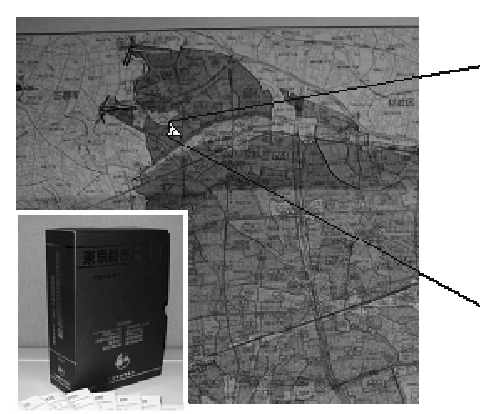

Urban Planning Map

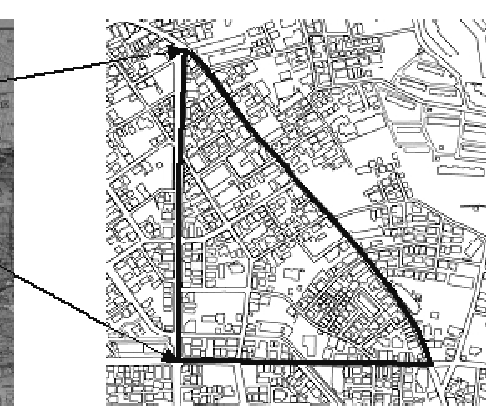

GIS Data
Fig.1 Survey Method of Blocks Density

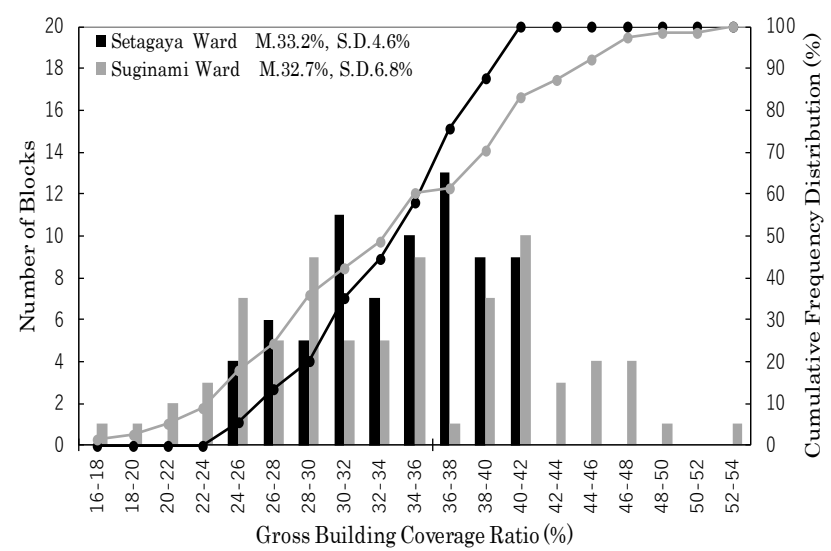

Fig.2 Status of Blocks Density

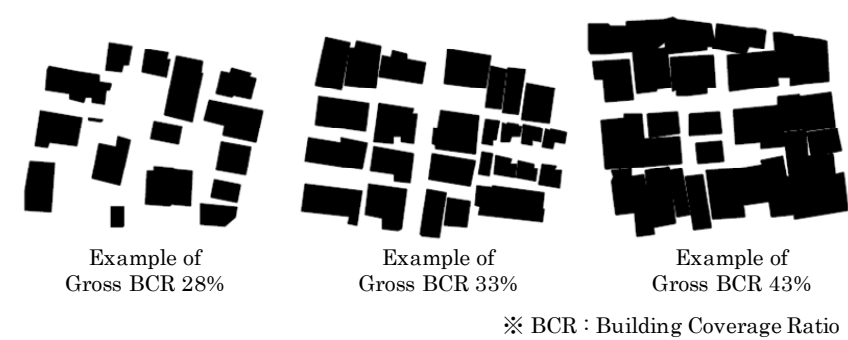

Fig.3 Examples of Gross BCR of Real Residential Blocks

3. 風洞実験による街区状況と風圧係数分布との関係の把握 3.1 風洞実験の概要

実験は東京大学工学部風環境シミュレータ実験室内にある風洞実 験装置を使用した。測定洞は一辺が $1.8 \mathrm{~m}$ の正方形断面、全長は $15.6 \mathrm{~m}$ であり、測定洞入り口から $12.5 \mathrm{~m}$ の位置に設けられた直径 $1.6 \mathrm{~m}$ のターンテーブルにより風向角の設定を可能としている。風 洞気流は模型軒高さ $(\mathrm{H}=59 \mathrm{~mm})$ での風速を基準風速 $(7 \mathrm{~m} / \mathrm{s})$ とし、 建築物荷重指針 9）の粗度区分 III（住宅地：べき指数 $0.2 ）$ の鉛直風 速プロファイルとした

(Fig.4)。風圧測定用 模型は Fig. 5 に示すよ うに平面・屋根形状の 異なる 5 種類とし、タ ーンテーブルの中央に 配置した。各種類の模 型の壁面および屋根面 に風圧測定点を設け、 風洞内のピトー管静圧 との差圧を測定した。

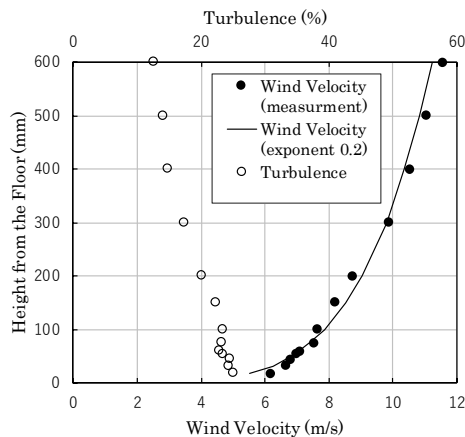

Fig.4 Approach Flow

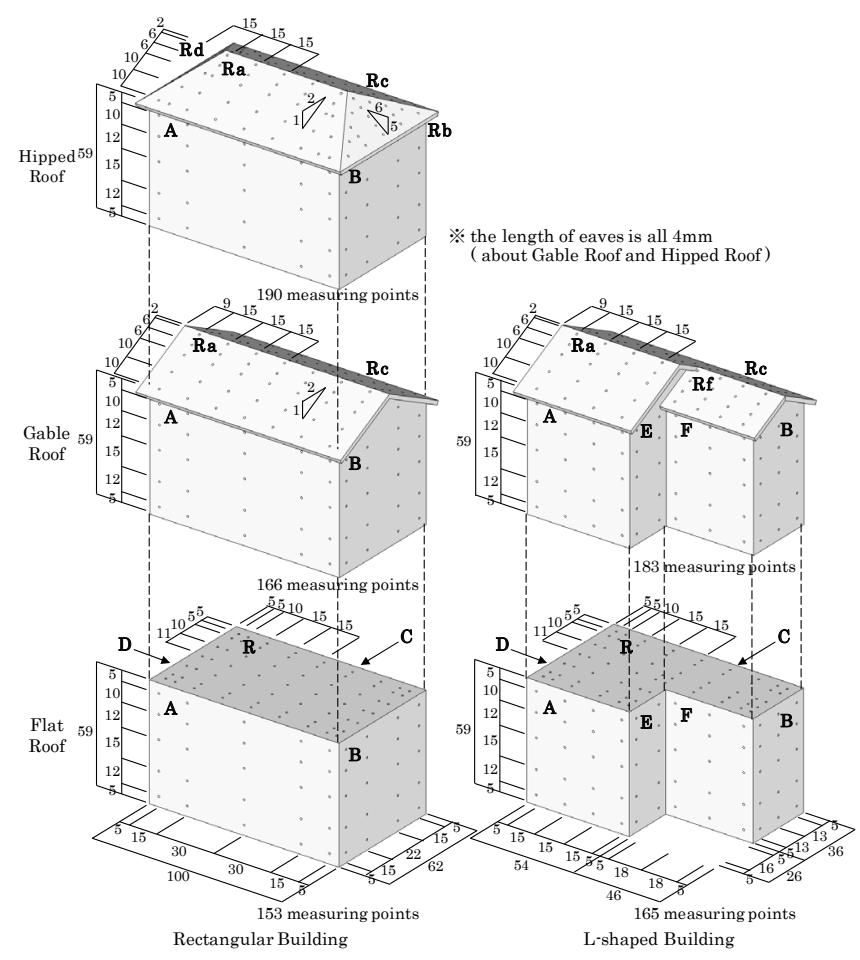

Fig.5 Measuring Models (scale:1/100, unit:mm) 


\section{2 街区密度の影響の評価}

矩形平面 - 切妻屋根の風圧測定用模型について、周辺模型を均等 配置（Fig.6）しグロス建蔽率を 23〜43\%（5\%刻み）で変更した場 合の各壁 - 屋根面に作用する平均風圧係数の風向変化を Fig.7 に示 す。妻面側の壁面 B は、風上側となるときにグロス建蔽率によって 平均風圧係数のばらつきが見られるが、その他の面についてはグロ 又建蔽率の違いによる大きな平均風圧係数の差は見られない。
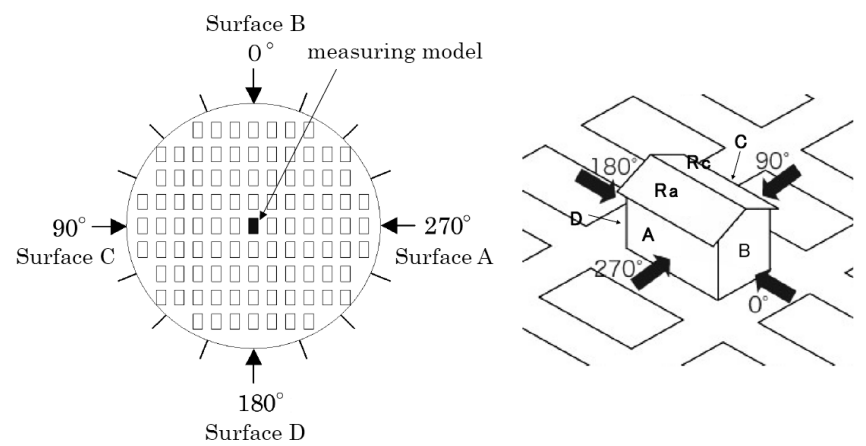

Surface D

Fig.6 Layout of Models (distributed simplified dense)
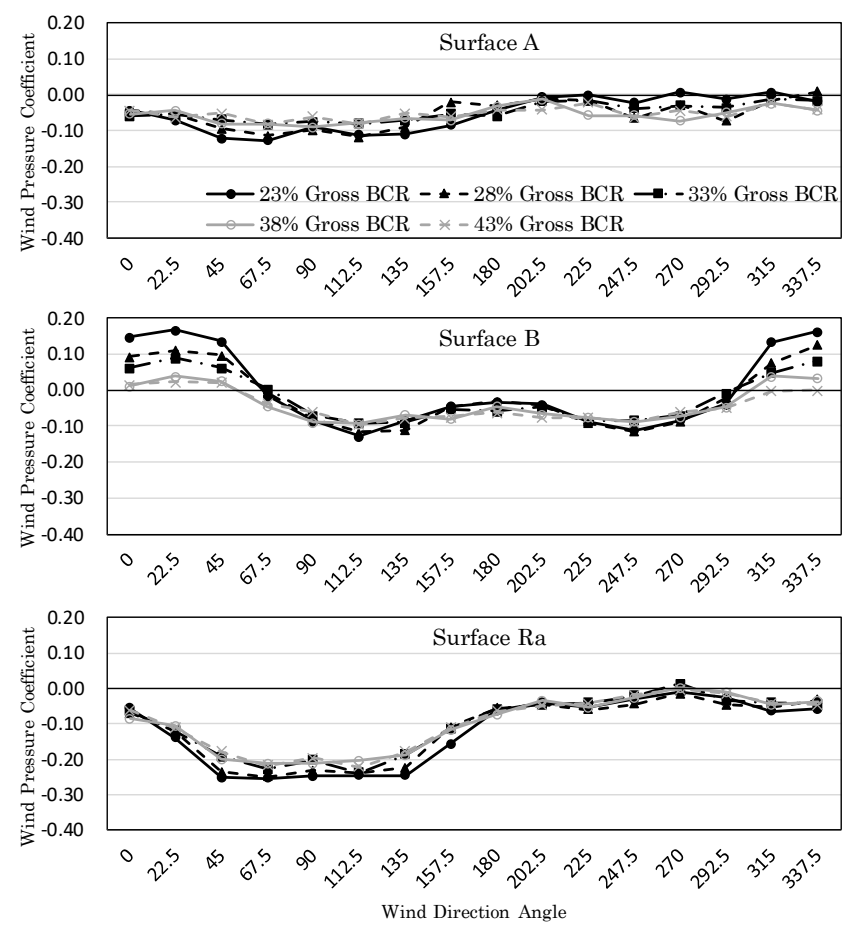

Fig.7 Average Wind Pressure Coefficient on each Wall Surface for all Wind Directions (distributed simplified dense)

Fig.8 に、矩形平面・切妻屋根の風圧測定用模型について風向角 $45^{\circ}$ の場合での、グロス建蔽率 $33 \%$ での全測定点の風圧係数を横軸 に、グロス建蔽率 $23 \% 、 28 \% 、 38 \% 、 43 \%$ での全測定点の風圧係数 を縦軸にとり、グロス建蔽率 $33 \%$ を基準とした各建蔽率での風圧係 数の相関を示寸。図のようにグロス建蔽率と風圧係数には高い相関 があり、近似直線の傾きからグロス建蔽率の増加とともに風圧係数 の絶対值が小さくなることが分かる。しかし、38\%と $43 \%$ の傾きに ほとんど変化が見られないことから、40\%付近に風圧係数の変化の 下限が予想される。この結果は、Table 1 で示すように矩形平面・ 切妻屋根形状のその他の風向角についても、またTable 2 で示すよ
うに他形状の風圧測定用模型についても同様であった。

以上より、特定のグロス建蔽率での各面の風圧係数を把握できれ ば他のグロス建蔽率での風圧係数も予測できることがわかる。本研 究では以後の実験についてグロス建蔽率 $33 \%$ を基本の街区密度と して検討を行った。

Table 1 Inclination of the Trendline based on 33\% Gross BCR (Rectangular Building, Gable Roof)

\begin{tabular}{c|c|c|c|c|c|c|c|c}
\hline \multirow{2}{*}{$\begin{array}{c}\text { Wind } \\
\text { Direction } \\
(\circ)\end{array}$} & \multicolumn{9}{|c|}{ Gross BCR (Building Coverage Ratio) } \\
\cline { 2 - 9 } & \multicolumn{2}{|c|}{$23 \%$} & \multicolumn{2}{c|}{$28 \%$} & \multicolumn{2}{c|}{$38 \%$} & \multicolumn{2}{c}{$43 \%$} \\
\cline { 2 - 9 } & inclination & R2 & inclination & R2 & inclination & R2 & inclination & R2 \\
\hline 0 & 1.52 & 0.91 & 1.18 & 0.93 & 0.74 & 0.84 & 0.63 & 0.80 \\
\hline 22.5 & 1.33 & 0.93 & 1.07 & 0.98 & 0.77 & 0.93 & 0.72 & 0.94 \\
\hline 45 & 1.36 & 0.94 & 1.22 & 0.97 & 0.85 & 0.94 & 0.84 & 0.96 \\
\hline 67.5 & 1.03 & 0.94 & 1.00 & 0.99 & 0.82 & 0.96 & 0.88 & 0.96 \\
\hline 90 & 1.19 & 0.95 & 1.05 & 0.98 & 0.95 & 0.97 & 0.90 & 0.97 \\
\hline
\end{tabular}

Table 2 Inclination of the Trendline based on 33\% Gross BCR $\left(\right.$ Wind Direction $\left.=0^{\circ}\right)$

\begin{tabular}{c|c|c|c|c|c|c|c|c}
\hline \multirow{2}{*}{$\begin{array}{c}\text { Type of } \\
\text { Measuring Model }\end{array}$} & \multicolumn{7}{|c|}{ Gross BCR (Building Coverage Ratio) } \\
\cline { 2 - 10 } & inclination & R2 & inclination & R2 & inclination & R2 & inclination & R2 \\
\hline $\begin{array}{c}\text { Rectangular Building, } \\
\text { Flat Roof }\end{array}$ & 1.56 & 0.92 & 1.20 & 0.97 & 0.76 & 0.93 & 0.74 & 0.92 \\
\hline $\begin{array}{c}\text { Rectangular Building, } \\
\text { Gable Roof }\end{array}$ & 1.52 & 0.91 & 1.18 & 0.93 & 0.74 & 0.84 & 0.63 & 0.80 \\
\hline $\begin{array}{c}\text { L-shaped Building, } \\
\text { Flat Roof }\end{array}$ & 1.35 & 0.92 & 1.26 & 0.94 & 0.89 & 0.97 & 0.83 & 0.94 \\
\hline
\end{tabular}

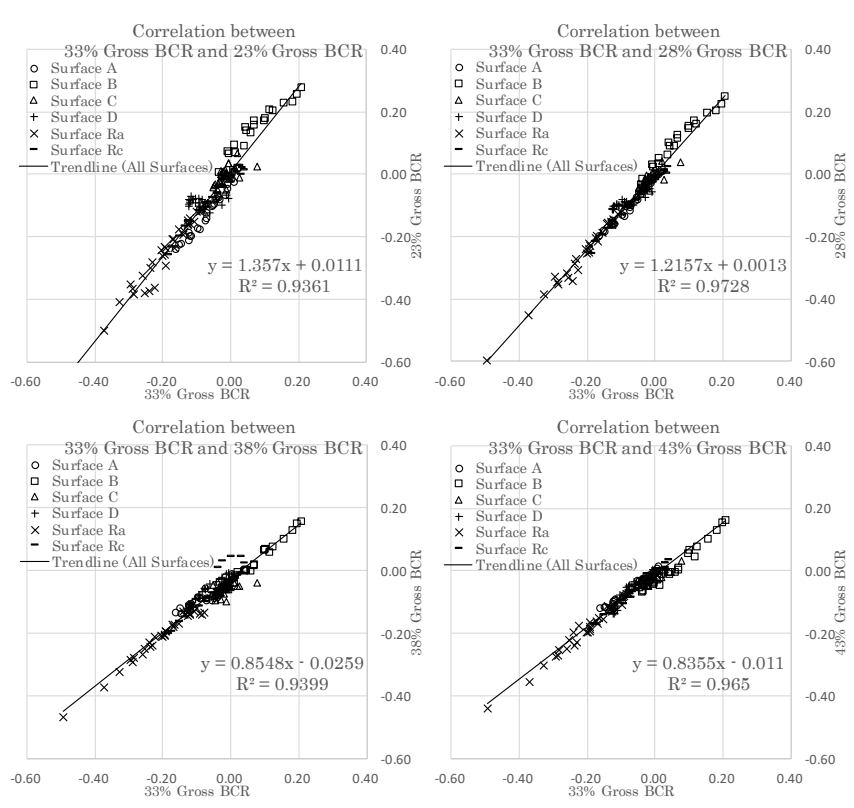

Fig.8 Correlation of Wind Pressure Coefficient by Block Density (Rectangular Building, Gable Roof, Wind Direction $=45^{\circ}$ )

\section{3 街区形状・街区内位置の影響の評価}

街区内道路と建物との関係は、通風を効果的に利用する上で考慮 しなければならない要素である。そこで、均等配置に加え、街区密 度調査の結果に基づいたグロス建蔽率 28～38\%（5\%刻み）のモデ ル街区を作成し、街区形状・街区内位置による各壁・屋根面に作用 する平均風圧係数の比較を行った。Fig.9 に検討した街区形状・街 
区内位置（街区中央・街区角）の周辺模型配置を、Table 3 に周辺 模型の隣棟間隔を示す。実験は、風圧測定用模型（Fig.5）のうち、 矩形平面・切妻屋根の模型を用いて行った。

Table 3 Distance from Surrounding Building

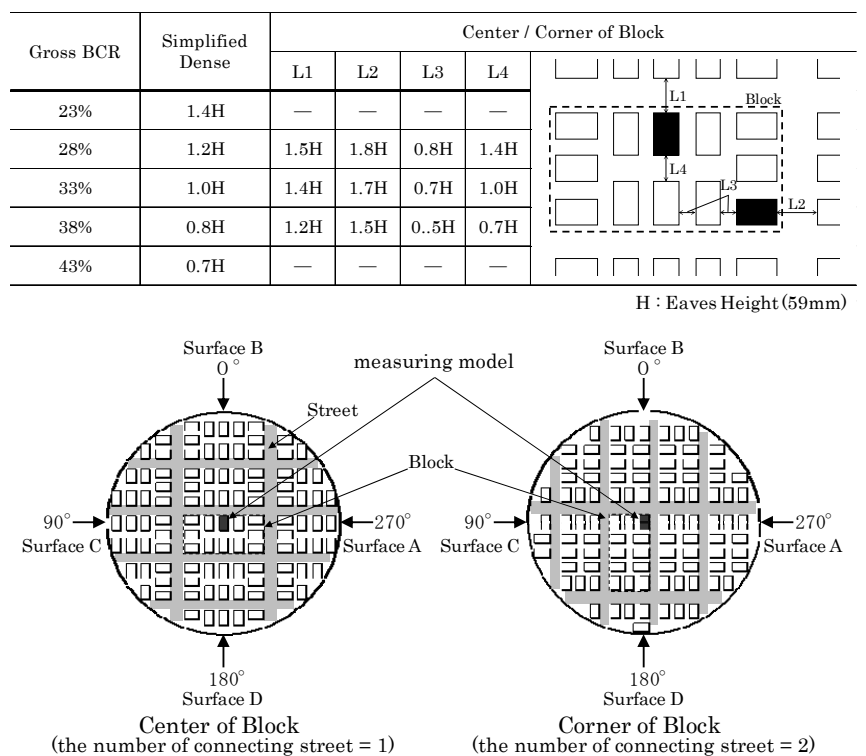

Fig.9 Layout of Models (located Center / Corner of Block)
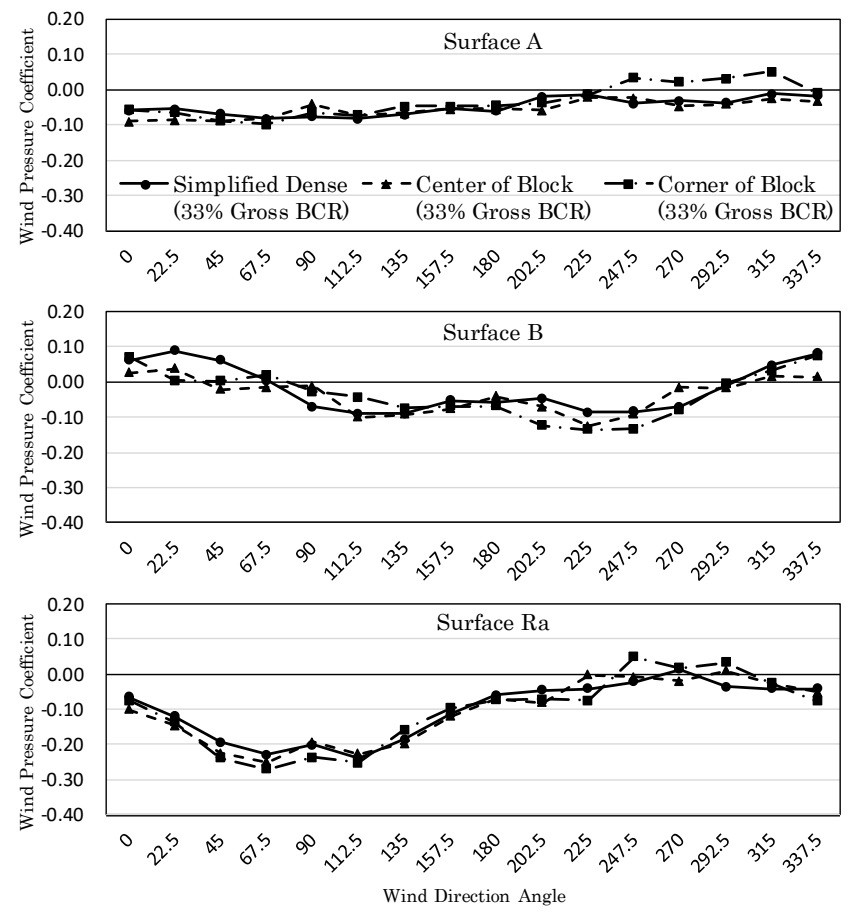

Fig.10 Average Wind Pressure Coefficient on each Surface for all Wind Directions studying the Building Location within the Block

Fig.10 にグロス建蔽率 $33 \%$ での均等配置・街区中央・街区角にお ける各壁・屋根面に作用する平均風圧係数の風向変化を示す。平面 側の壁面 $\mathrm{A}$ では、風上側となる風向角 $247.5 \sim 337.5^{\circ}$ の範囲で、前 面が道路となる街区角では正圧となり、均等配置および道路に面し ていない街区中央では負圧となっている。一方で、妻面側の壁面 B
および屋根面 Ra については、街区形状の違いによる平均風圧係数 の風向変化に顕著な違いは見られない。一般的に街区角は通風上有 利な立地であると考えられるため、本研究ではより通風に不利な街 区中央と同様の平均風圧係数の風向変化を示寸均等配置を用いて、 以後の実験を行った

\section{4 屋根形状の影響の評価}

屋根形状による屋根面に作用する風圧力への影響を正しく把握す るために、グロス建蔽率 $33 \%$ で均等配置した模型の中央に矩形平面 の風圧測定用模型を設置し、屋根形状を陸屋根・切妻屋根・寄棟屋 根に変化させて実験を行った。Fig.11に屋根形状による屋根面平均 風圧係数の風向変化を示す。陸屋根は風向角によらず常に -0.05 程 度の負圧となった。一方で、切妻屋根および寄棟屋根では、風下側 となる風向角 $0 \sim 180^{\circ}$ で比較的大きな負圧となる。この結果は、密 集した住宅地において屋根面に開口を設ける場合、ある程度勾配の ある方が通風に有利となることを示している。なお、切妻屋根の屋 根面 $\mathrm{Ra}$ と寄棟屋根の屋根面 $\mathrm{Ra} の$ 平均風圧係数の風向変化は、風 向角の違いによって概ね同様の傾向を示している。また、寄棟屋根 では屋根面 $\mathrm{Ra}$ と屋根面 $\mathrm{Rb}$ で平均 0.11 程度の比較的大きい風圧係 数差が確保できることが確認された。

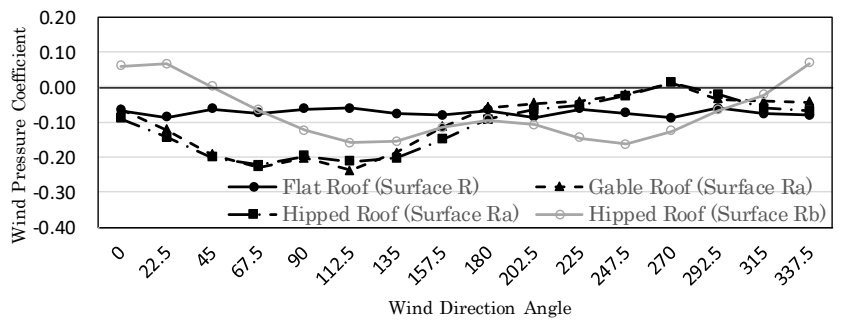

Fig.11 Average Wind Pressure Coefficient on each Roof Surface for all Wind Directions studying the Roof Types

\section{4. 風洞実験による隣棟高さ・距離の影響の評価}

前章では、グロス建蔽率と各面の平均風圧係数には高い相関があ るため特定のグロス建蔽率での風圧係数を把握できれば他のグロス 建蔽率での風圧係数も予測できることを明らかにした。また、街区 形状・街区内位置あるいは屋根形状による壁面および屋根面に作用 する風圧力への影響を検証した。本章では前章の検討結果を受けて、
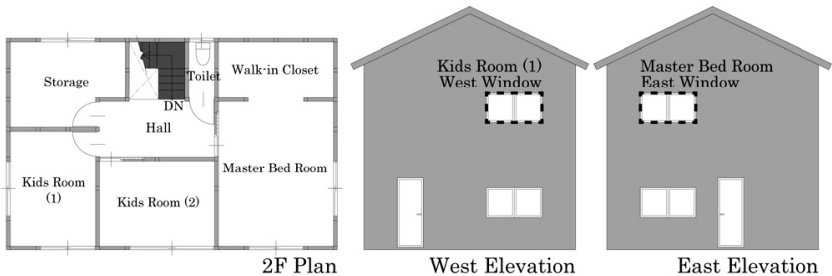

West Elevation East Elevation
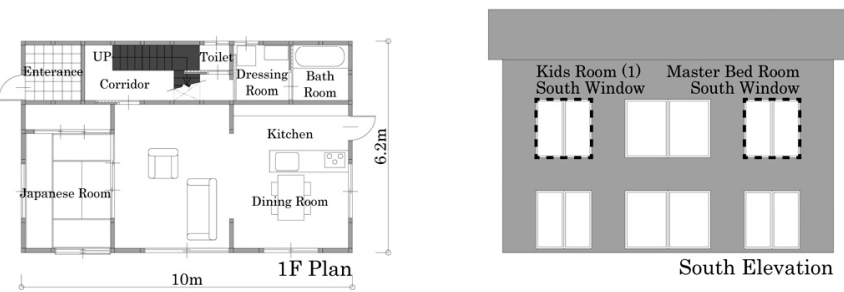

Fig.12 Plan / Elevation of Model House 
風圧測定用模型は矩形平面・切妻屋根とし、グロス建蔽率 33\%（均 等配置）で隣棟高さおよび距離が変化した場合の各面に作用寸る風 圧力への影響を検証する。加えて、矩形平面・切妻屋根の風圧測定 用模型について Fig.12 に示すモデル建物を想定し、周辺建物状況の 変化が各室（リビングダイニング・和室・主寝室・子供室(1)）の壁 面に設けた開口部間の風圧係数差の風向変化についての考察も行う。

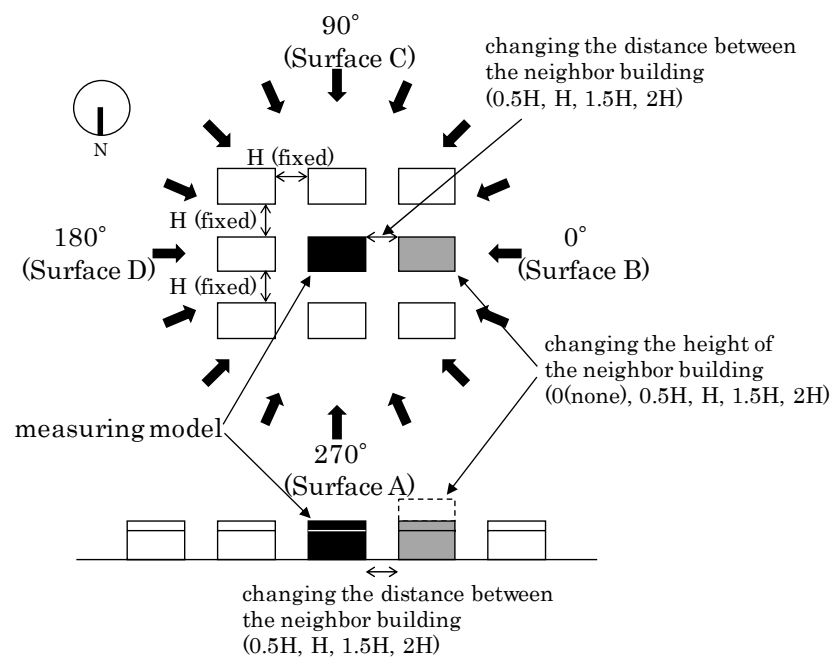

Fig.13 Overview of WT Test (Changing Surface B Side)
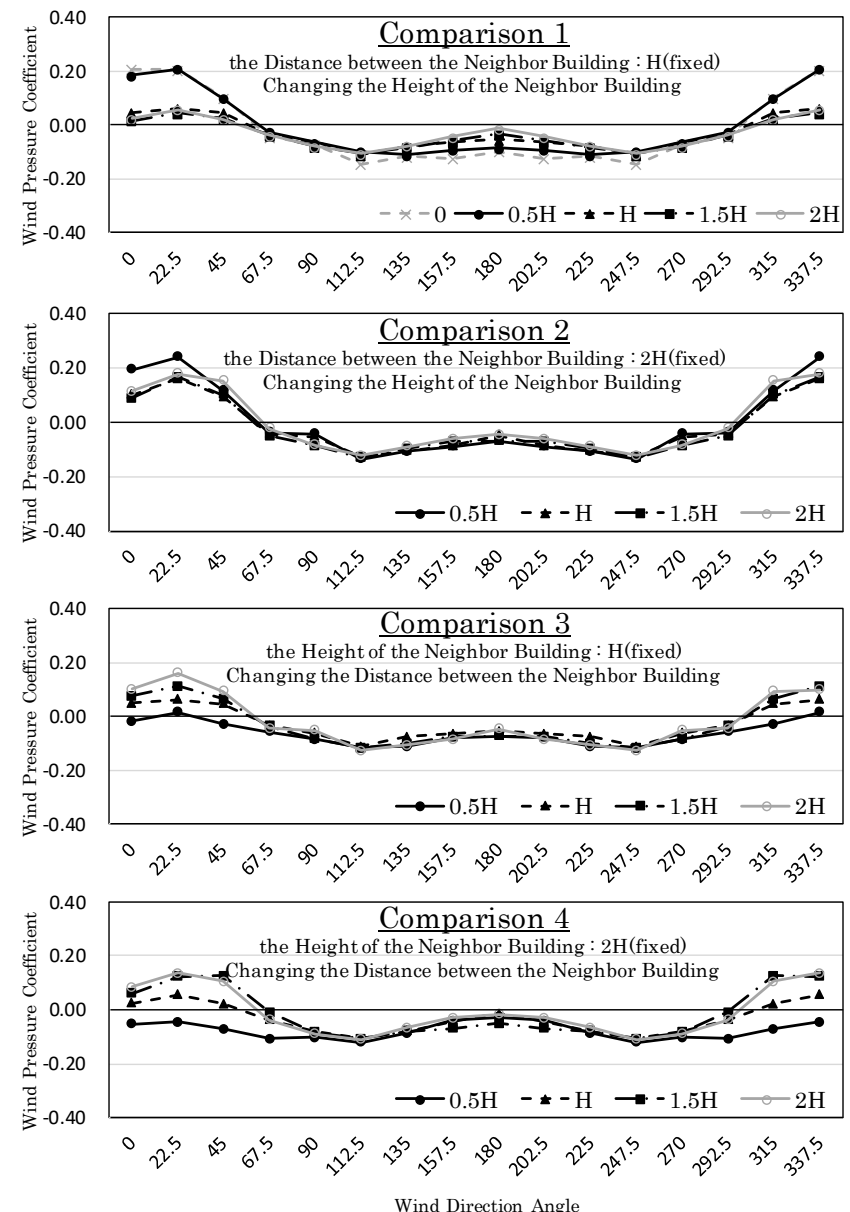

Fig.14 Average Wind Pressure Coefficient on Surface B for all Wind Directions (Changing Surface B Side)

\section{1 妻面側の隣棟高さ・距離の影響の評価}

妻面である壁面 B 側の隣棟高さおよび距離を変化させて実験を行 う。実験概要を Fig.13 に、実験ケースを Table 4 に示す。

Fig.14 に各比較ケースでの壁面 B の平均風圧係数の風向変化を 示す。隣棟距離を $\mathrm{H}$ に固定した場合、壁面 $\mathrm{B}$ は風向角が $0 \pm 45^{\circ}$ の 範囲では隣棟高さが 0 (なし) 、 $0.5 \mathrm{H}$ の方が平均風圧係数は $0.1 \sim 0.2$ 程度大きくなる。壁面 $\mathrm{B}$ のその他の風向角あるいはその他の面の平 均風圧係数は隣棟高さの変化による影響は見られない。隣棟距離を $2 \mathrm{H}$ に固定した場合は、壁面 $\mathrm{B}$ の風向角 $0 \pm 45^{\circ}$ の範囲で多少の隣 棟高さによる違いが見られるものの、隣棟距離が $\mathrm{H}$ の場合と比較す ると隣棟高さの変化による影響は大きくは見られない。隣棟高さを $\mathrm{H} 、 2 \mathrm{H}$ に固定した場合、壁面 $\mathrm{B}$ はいずれも風向角が $0 \pm 67.5^{\circ}$ の

Table 4 Cases of WT Test (Changing Surface B Side)

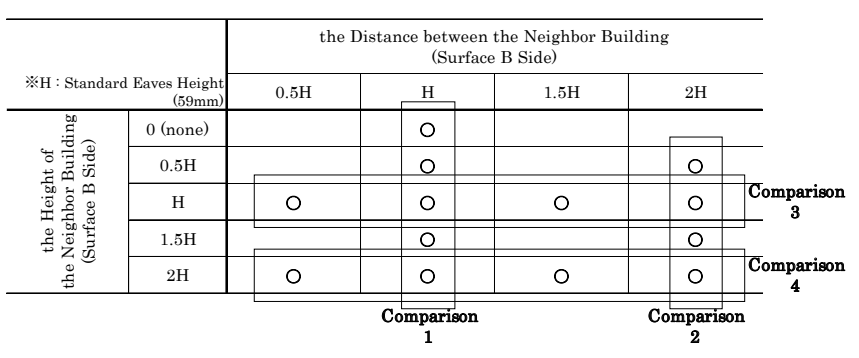
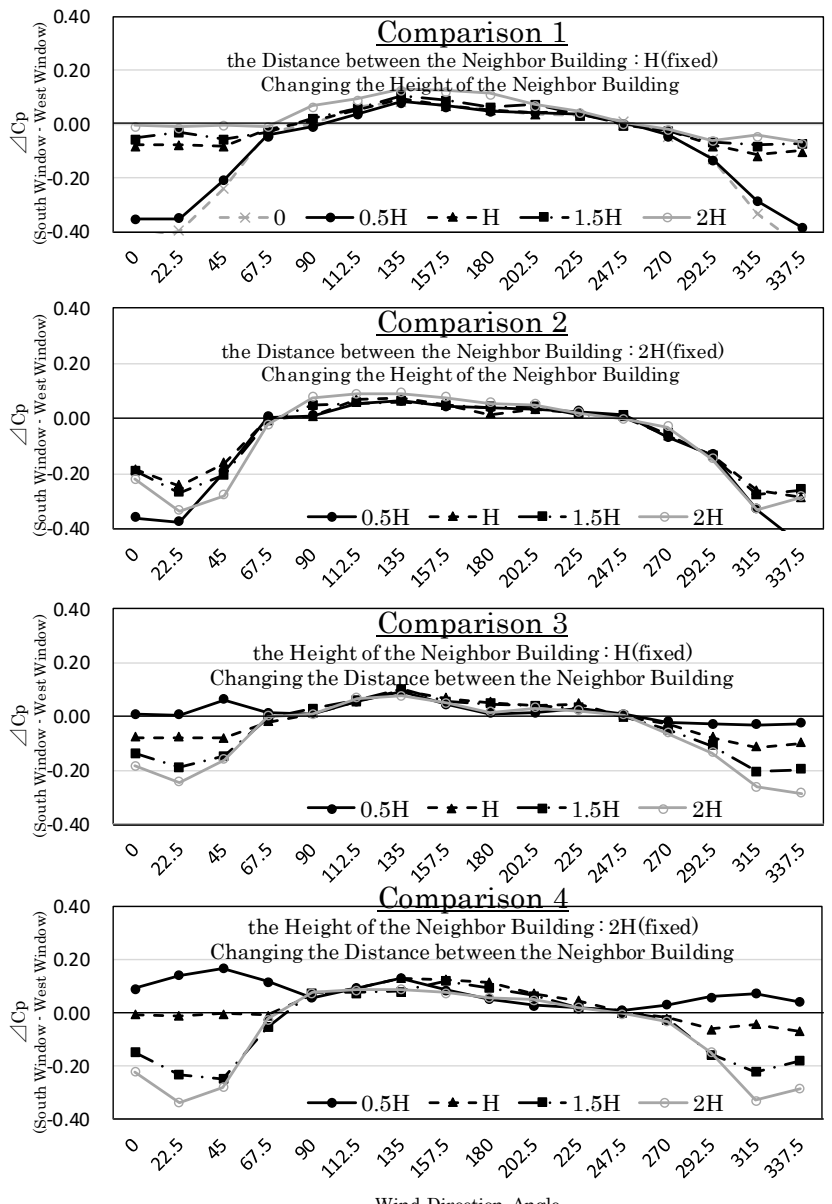

Wind Direction Angle

Fig.15 $\Delta \mathrm{Cp}$ (South Window - West Window) on Kids Room (1) for all Wind Directions (Changing Surface B Side) 
範囲で隣棟距離による違いが見られ、隣棟距離が $0.5 \mathrm{H}$ の場合は壁 面 B が風上側にある場合でも平均風圧係数は負の值となっている。

Fig.15 に子供室 (1)の壁面に設けた開口部間の風圧係数差 (=南面 開口-西面開口）の各比較ケースにおける風向変化を示す。壁面 $\mathrm{B}$

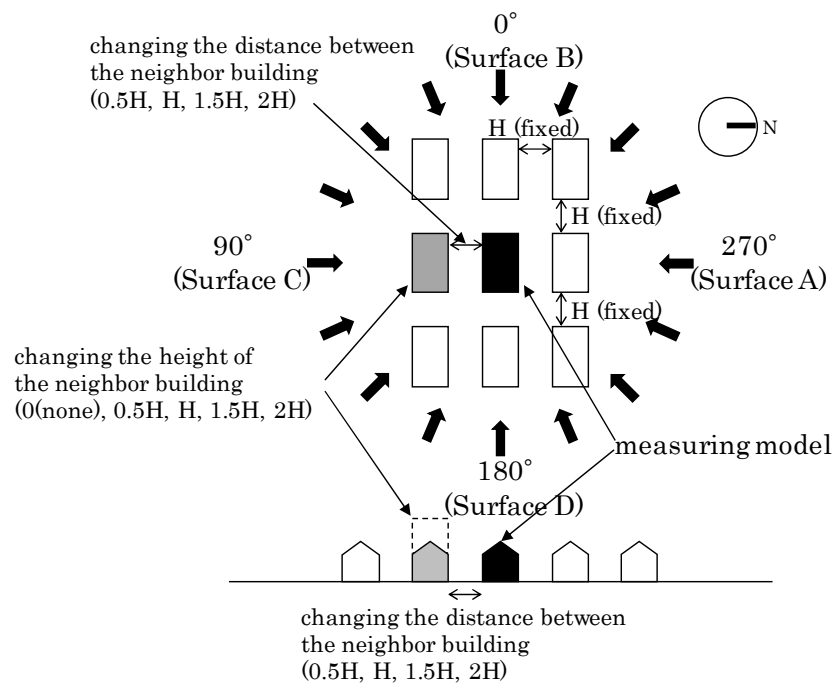

Fig.16 Overview of WT Test (Changing Surface C Side)
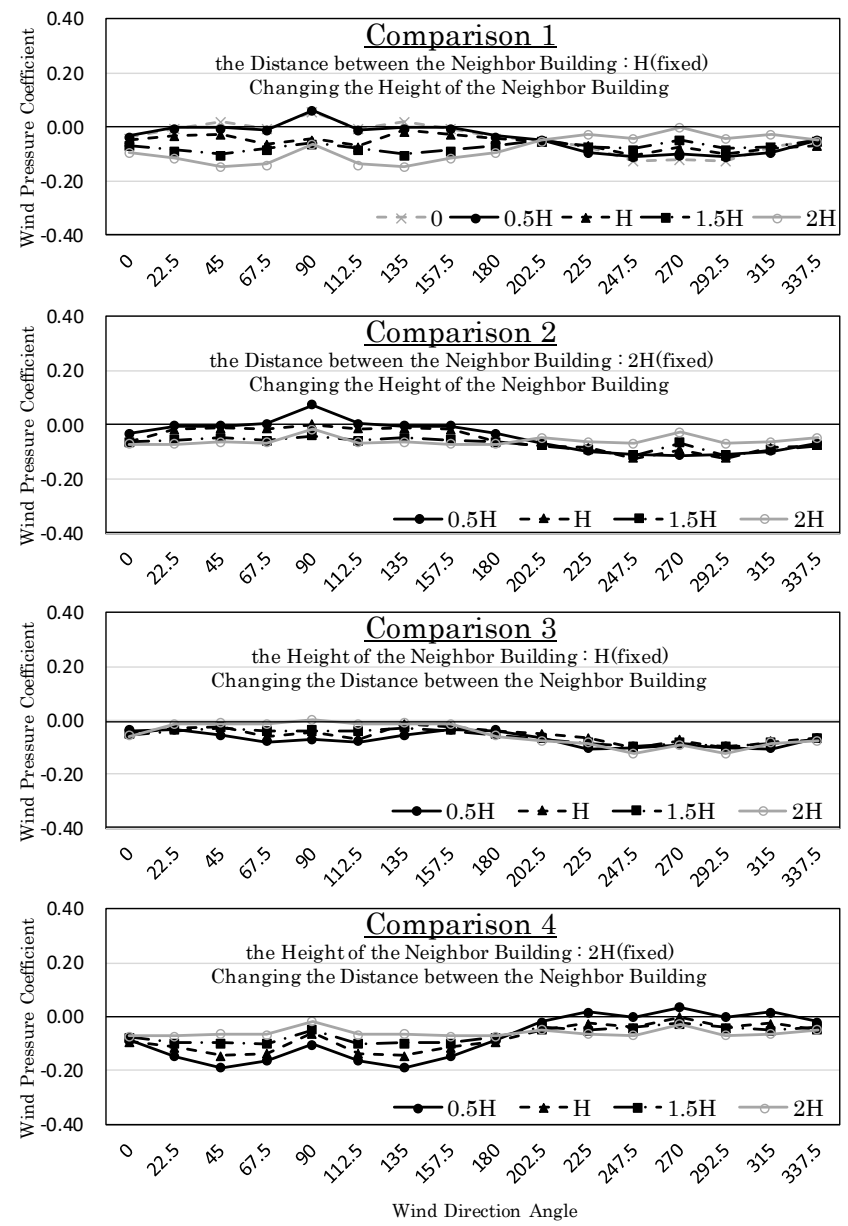

Fig.17 Average Wind Pressure Coefficient on Surface $C$ for all Wind Directions (Changing Surface $\mathrm{C}$ Side)
が風上側になる風向角を中心に、隣棟条件による風圧係数差の違い は、壁面 B の平均風圧係数の隣棟条件による違いより差が大きく、 密集住宅地において室の風圧係数差を確保し効果的に通風を行うた めには、より正確に隣棟条件を把握する必要があることがわかる。 また、比較ケース 4 において風上側に高さ $2 \mathrm{H}$ の隣棟が建つ場合も、 隣棟距離が $\mathrm{H}$ 以外の場合は十分な風圧係数差を確保できており、風 上側に高い建物がある場合でも一概に通風に不利とは言い切れない ことが示された。

\section{2 平面側の隣棟高さ・距離の影響の評価}

平面である壁面 $\mathrm{C}$ 側の隣棟高さおよび距離を変化させて実験を行

う。実験概要を Fig.16に、実験ケースを Table 5 に示す。

Table 5 Cases of WT Test (Changing Surface C Side)

\begin{tabular}{|c|c|c|c|c|c|c|}
\hline \multirow{2}{*}{\multicolumn{2}{|c|}{$\begin{array}{r}\text { H : Standard Eaves Height } \\
(59 \mathrm{~mm})\end{array}$}} & \multicolumn{4}{|c|}{$\begin{array}{l}\text { the Distance between the Neighbor Building } \\
\text { (Surface C Side) }\end{array}$} & \\
\hline & & $0.5 \mathrm{H}$ & $\mathrm{H}$ & $1.5 \mathrm{H}$ & $2 \mathrm{H}$ & \\
\hline \multirow{5}{*}{ 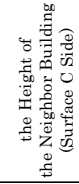 } & 0 (none) & & 0 & & & \multirow[b]{3}{*}{$\begin{array}{c}\text { Comparison } \\
\quad 3\end{array}$} \\
\hline & $0.5 \mathrm{H}$ & & 0 & & 0 & \\
\hline & $\mathrm{H}$ & 0 & 0 & 0 & 0 & \\
\hline & $1.5 \mathrm{H}$ & & 0 & & 0 & \multirow{3}{*}{$\begin{array}{c}\text { Comparison } \\
4\end{array}$} \\
\hline & $2 \mathrm{H}$ & 0 & 0 & 0 & 0 & \\
\hline \multicolumn{5}{|c|}{ Comparison } & $\begin{array}{c}\text { Comparison } \\
2\end{array}$ & \\
\hline
\end{tabular}
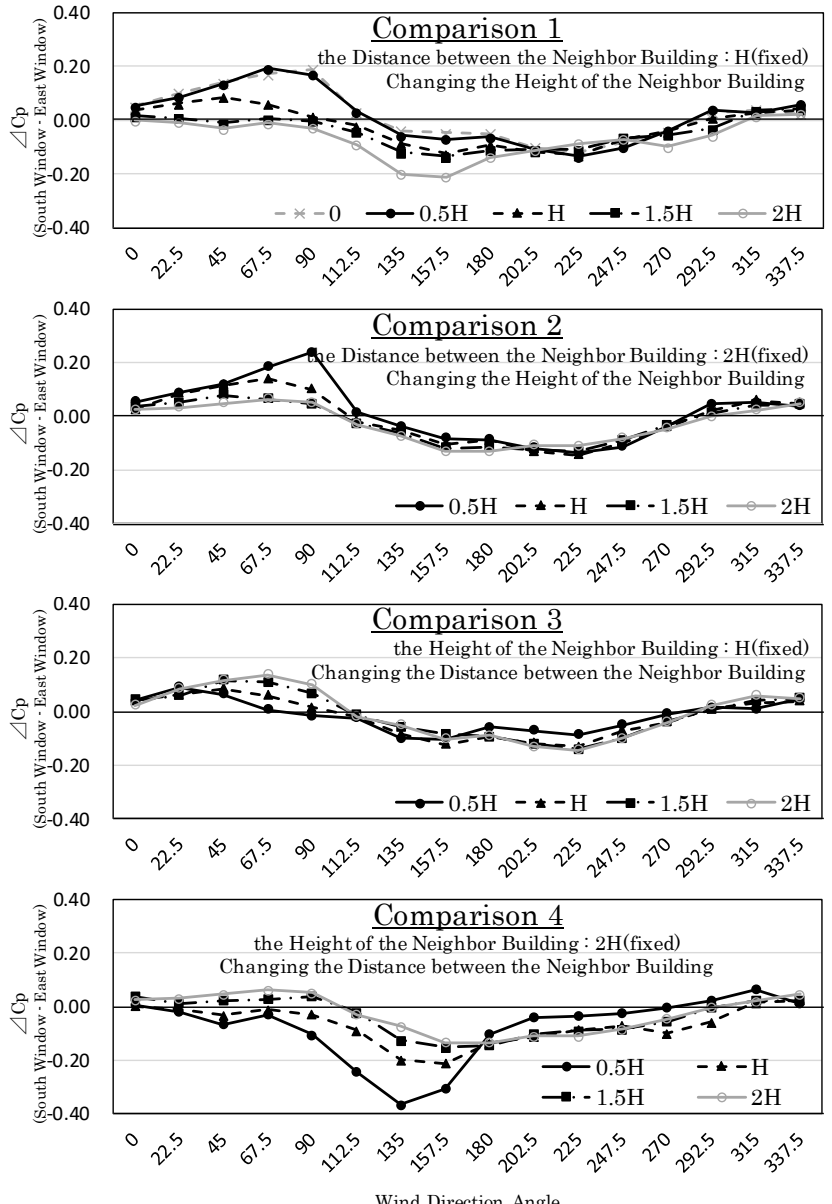

Fig.18 $\Delta \mathrm{Cp}$ (South Window - East Window) on Master Bed Room for all Wind Directions (Changing Surface $C$ Side) 
Fig.17 に各比較ケースでの壁面 $\mathrm{C}$ の平均風圧係数の風向変化を 示す。隣棟距離を $\mathrm{H}$ に固定した場合、壁面 $\mathrm{C}$ では隣棟高さによる 平均風圧係数の違いがほぼすべての風向角で見られる。特に隣棟高 さが 0 （なし）および $0.5 \mathrm{H}$ の場合と $2 \mathrm{H}$ の場合では、壁面 $\mathrm{C}$ が風 上側に来る場合は隣棟高さが 0 (なし) および $0.5 \mathrm{H}$ の方が平均風 圧係数は高く、風下側に来る場合は隣棟高さが $2 \mathrm{H}$ の方が平均風圧 係数は高くなるという正反対の傾向を示すことには注意が必要であ る。一方で、隣棟距離が $2 \mathrm{H}$ の場合は、 $\mathrm{H}$ の場合と比較して隣棟高 さによる平均風圧係数の違いはあまり見られない。また、隣棟高さ を $\mathrm{H}$ に固定した場合は、いずれの風向角においても隣棟距離の影響 は見られない。しかし、隣棟高さを $2 \mathrm{H}$ とした場合は、特に隣棟距 離を $0.5 \mathrm{H}$ あるいは $\mathrm{H}$ とすると風向角によって平均風圧係数が大き く異なる。上記はいずれも屋根面 Rc においても同様の傾向が見ら れた。

Fig.18 に主寝室の壁面に設けた開口部間の風圧係数差（=南面開 口-東面開口）の各比較ケースにおける風向変化を示す。いずれのケ 一スにおいても、壁面 $\mathrm{C}$ が風上側となる風向角 $90^{\circ}$ 付近を中心に 平均風圧係数の風向変化よりも隣棟の影響を大きく受けていること が見てとれる。特に隣棟条件次第では風圧係数差がほとんど確保で きなくなるケースについては、設計時から周辺建物状況を考慮した 綿密な開口部の設計が不可欠となる。

\section{5. 風洞実験による通風促進装置の効果検証}

前章では、隣棟高さおよび距離を変化させた場合に各面の平均風 圧係数に及ぼす影響を明らかにした。特にモデル建物を用いて検討 した開口部間の最大風圧係数差の風向変化については、隣棟の影響 をより大きく受けるため、周辺建物状況を正確に把握することの重 要性が示された。本章では引き続き、隣棟高さおよび距離を変化さ せて、坪庭あるいは越屋根といった通風促進装置に及ぼす影響を検 証する。

\section{1 坪庭による通風促進効果の検証}

星野ら 10) は密集住 宅地においても四方を 壁で囲われた中庭内部 は常に負圧に保たれ、 中庭に面した開口は安 定した流出口となるこ とを検証している。し かし、狭小の住宅にお いてはプランの制約上 中庭を設けることは難 しい。一方で京都の町

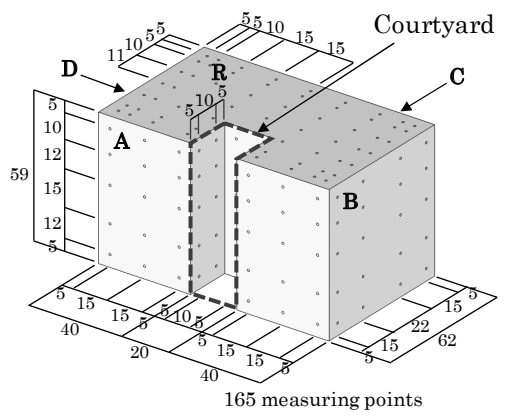

Fig.19 Measuring Model of Courtyard
屋に見られるような三方を壁、もう一方を外部空間に囲われた坪庭 の気流性状を把握すれば、狭小の住宅でも安定した通風経路を計画

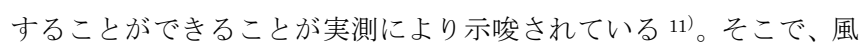
洞実験により坪庭の風圧係数分布を把握した。測定対象は矩形平 面・陸屋根の 2 階建住宅とする (Fig.19)。周辺建物はグロス建蔽率 $33 \%$ 均等配置とし、坪庭の面する隣棟高さおよび距離を Fig.20のよ うに変化させた。
各測定ケースの坪庭内の平均風圧係数と各ケースにおける坪庭と 外部に面した壁面との間での生じる最大風圧係数差（絶対值）を Fig. 21 に示す。風下側の隣棟を変化させた場合、隣棟高さが低い方 が坪庭内部の負圧は大きくなるが、隣棟高さが $2 \mathrm{H}$ の場合は逆流に より、坪庭内部は正圧となっている。しかし、坪庭内部が正圧とな った場合でも、外部に面した壁面との間で比較的大きな風圧係数差 が確保されており、坪庭に面した開口を風の入口とした通風経路を 計画できることが示唆される。一方で、風上側の隣棟を変化させた 場合は隣棟高さが高い方が坪庭内部の負圧は大きくなる。特に風向 角が $45^{\circ}$ のときには、隣棟高さが $2 \mathrm{H}$ になると検討ケースのうち最 も大きな負圧が作用し、外部に面した壁面との間でも大きな風圧係 数差が確保できている。

以上より、隣地条件を考慮して卓越風を正しく把握できれば坪庭 を介した効果的な通風経路を計画できることがわかる。

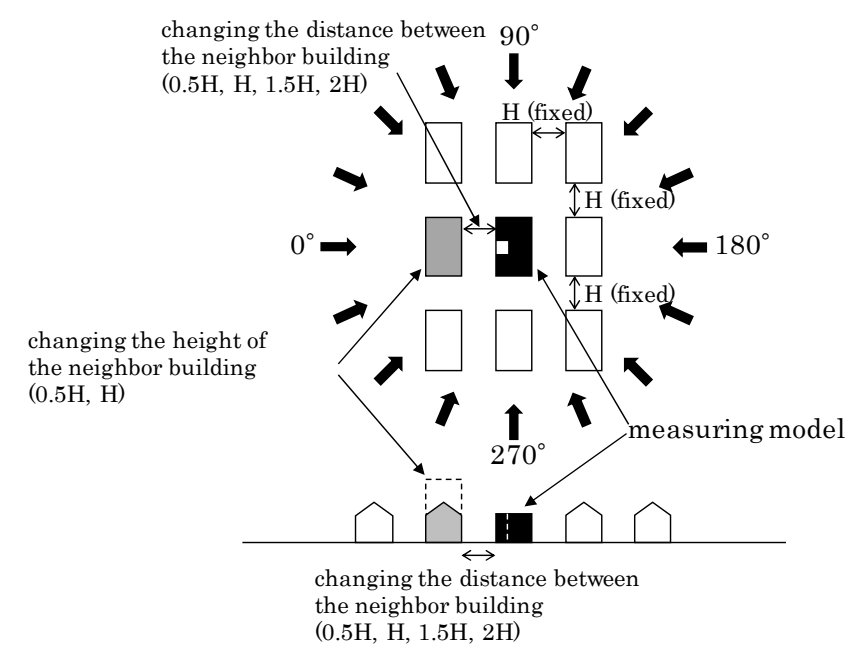

Fig.20 Overview of WT Test (Courtyard)

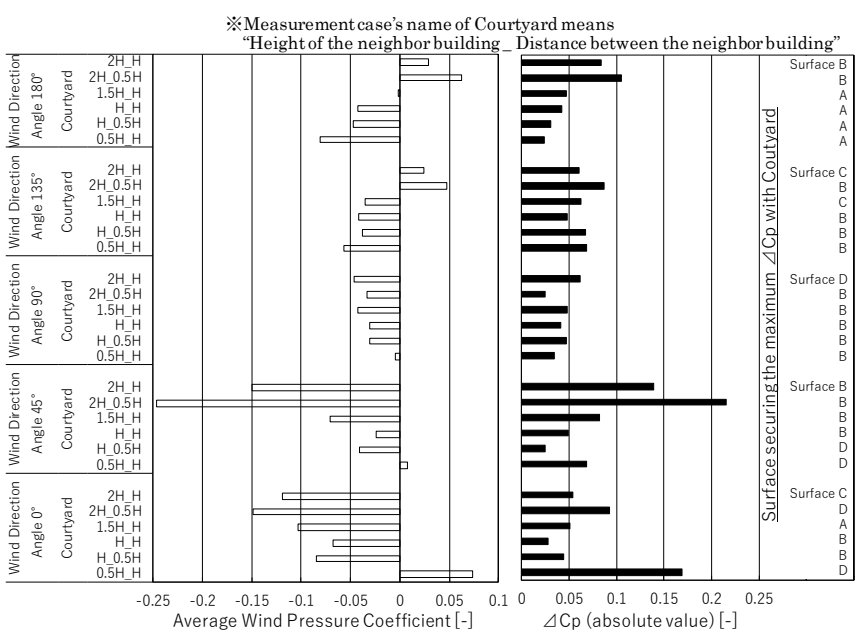

Fig.21 Average Wind Pressure Coefficient on the Courtyard Surface and Maximum $\triangle \mathrm{Cp}$ between Courtyard and Other Wall for all Wind Directions

\section{2 片流れ屋根・越屋根による通風促進効果の検証}

太陽光あるいは太陽熱利用を最大化するために、片流れ屋根を採 用する住宅は多い。一方で、片流れ屋根は切妻や陸屋根などと比べ 方位性を持つため、敷地の卓越風向や隣棟の影響をより正しく把握 
する必要がある。また、その片流れ屋根に日本の伝統的な住宅によ く見られる越屋根と呼ばれる換気・採光用の装置を設けた場合の気 流性状の把握も、より効果的な通風利用には重要である。そこで、 風洞実験において Fig. 22 に示寸風圧測定用模型のまわりにグロス 建蔽率 $33 \%$ で均等に周辺建物を配置し、隣棟の高さが変化（高さ $\mathrm{H}$ または $2 \mathrm{H} ）$ した場合の各風向角での風圧係数を測定し、片流れ屋 根および越屋根の気流性状を把握した。Fig.23に実験概要、Table 6 に測定ケースを示す。

越屋根なし／ありそれぞれの測定ケースについて、隣棟高さの変 化が屋根面に与える影響を Fig. 24 および Fig.25 に示す。Fig.24で 示すように、越屋根がない場合屋根面（R 面）はどのケースでも比 較的安定して負圧となっている。特に A 面側の隣棟が高いケース(図 中の凡例 で示寸ケース）では風向角の変化による屋根面の平均風 圧係数の差が最も小さい。一方で、C 面側の隣棟が高いケース（図 中の凡例西で示すケース）は、風向角が $0 \pm 22.5^{\circ}$ の範囲では屋根 面（R 面）に作用寸る平均風圧係数が正圧となっている。Fig.25 で 示寸ように、越屋根がある場合でも、屋根面（R 面）の平均風圧係

Table 6 Cases of WT Test (Shed Roof / Roof Monitor)

\begin{tabular}{c|c|c|c|c}
\hline & Equal Height & $\begin{array}{c}\text { Neighbor Building } \\
\text { Height of Surface } \\
\text { A Side }: 2 \mathrm{H}\end{array}$ & $\begin{array}{c}\text { Neighbor Building } \\
\text { Height of Surface } \\
\text { B Side }: 2 \mathrm{H}\end{array}$ & $\begin{array}{c}\text { Neighbor Building } \\
\text { Height of Surface } \\
\text { C Side }: 2 \mathrm{H}\end{array}$ \\
\hline $\begin{array}{c}\text { Shed Roof } \\
\text { (without Roof Monitor) }\end{array}$ & 0 & 0 & 0 & 0 \\
\hline $\begin{array}{c}\text { Shed Roof } \\
\text { (with Roof Monitor) }\end{array}$ & 0 & 0 & 0 & 0 \\
\hline
\end{tabular}

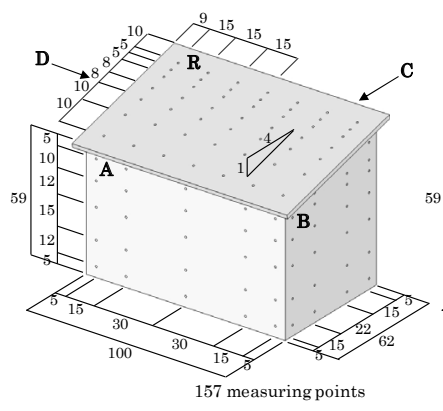

Shed Roof Model (without Roof Monitor)

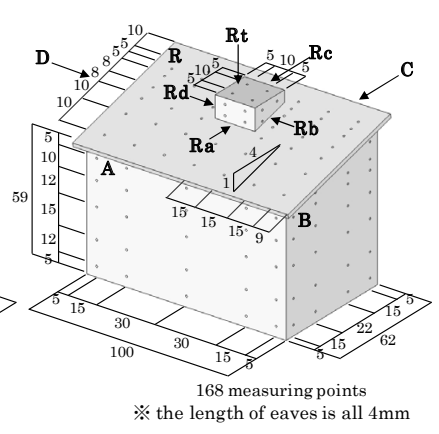

Shed Roof Model (with Roof Monitor)
Fig.22 Measuring Models of Shed Roof / Roof Monitor

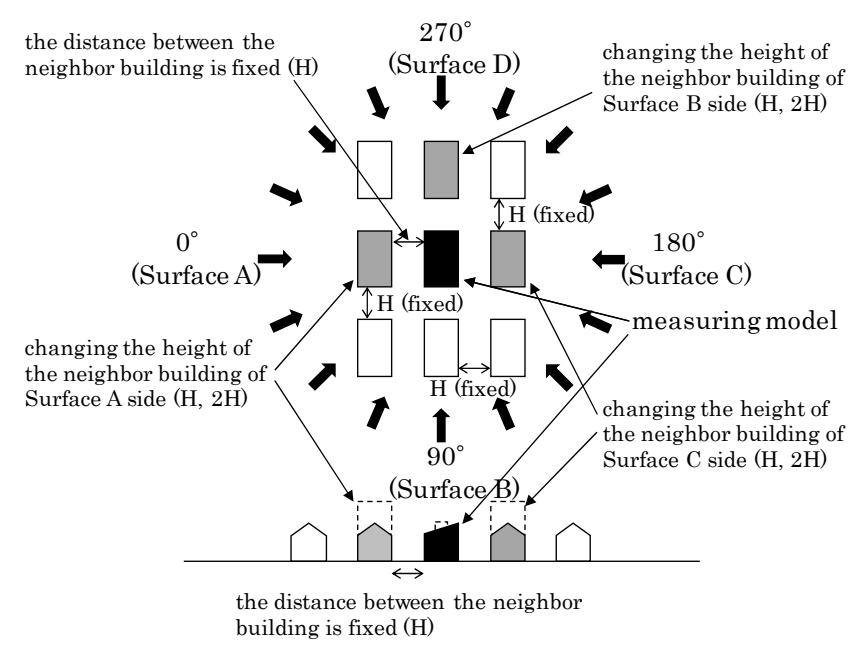

Fig.23 Overview of Wind Tunnel Test (Shed Roof / Roof Monitor)

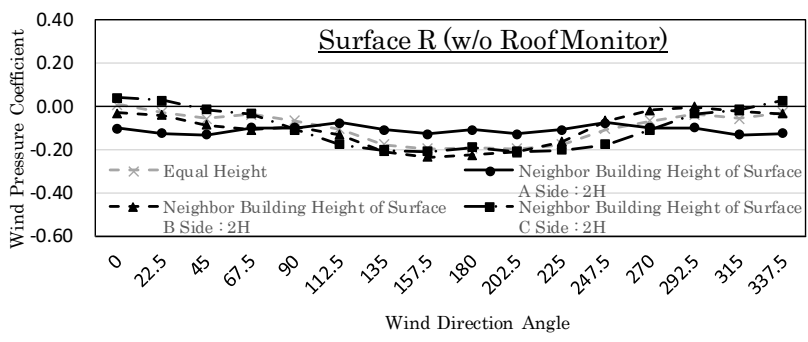

Fig.24 Average Wind Pressure Coefficient on Surface R for all Wind Directions (Shed Roof w/o Roof Monitor)
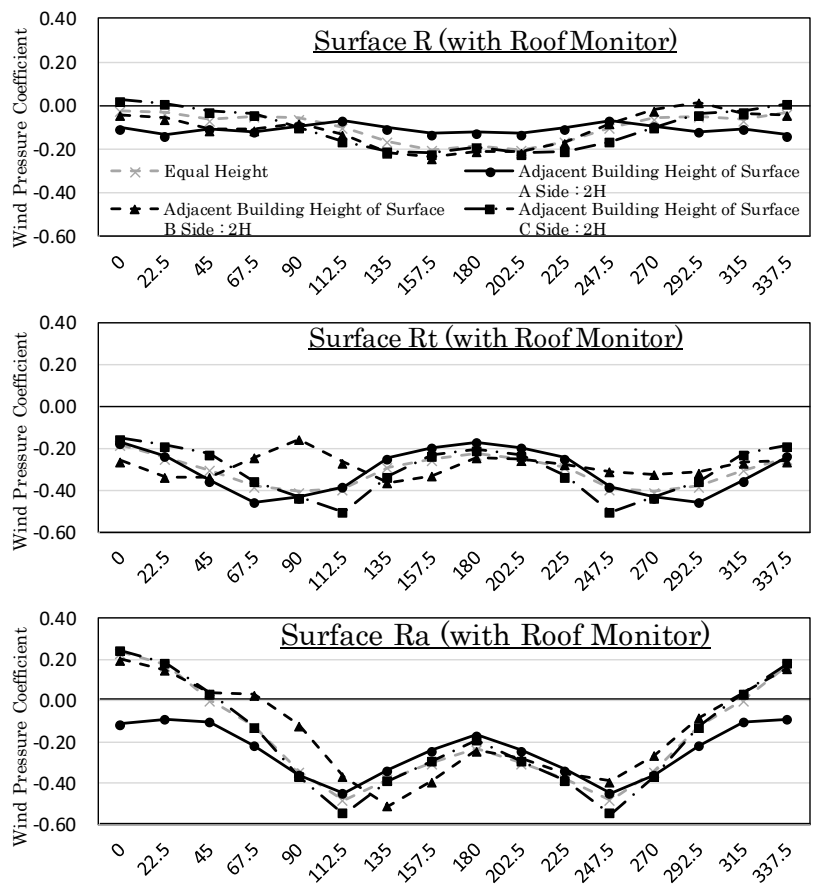

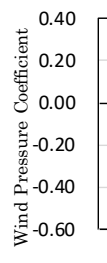

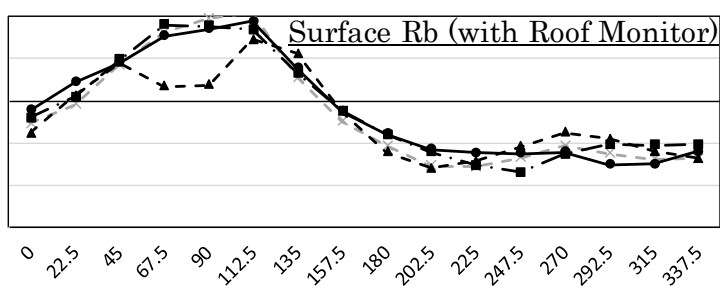

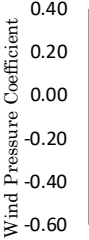

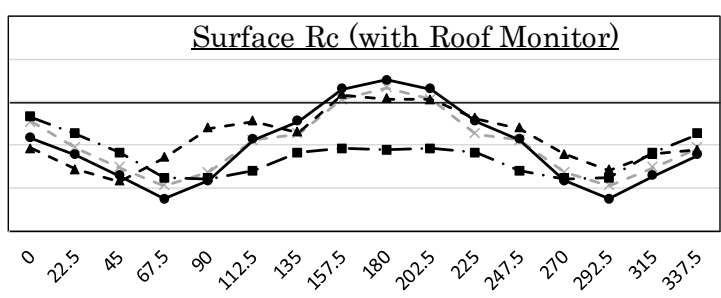

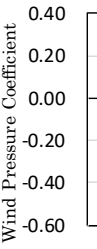

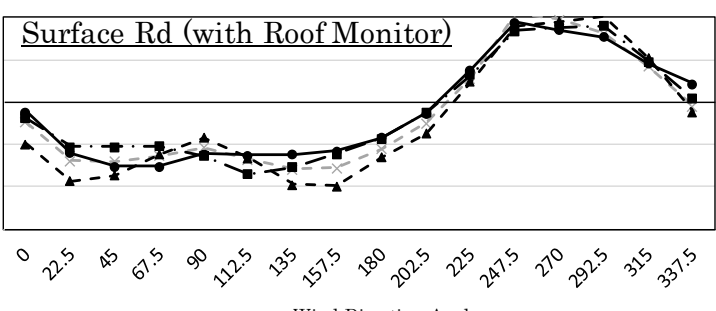

Fig.25 Average Wind Pressure Coefficient on each Surface for all Wind Directions (Shed Roof with Roof Monitor) 
数は越屋根がない場合と概ね同様の傾向を示す。しかし、越屋根の 側面（Ra〜 Rd 面）は建物壁面とは異なり、風上側にあるときには 大きな正圧が作用する。また、 $\mathrm{A} \sim \mathrm{C}$ 面側のいずれの隣棟が高くした 場合でも $\mathrm{Rd}$ 面の平均風圧係数は均等配置の場合とほぼ同じ風向変 化を示す。このことから、越屋根の側面に開口を設ける場合は、卓 越風向ととともにその開口の面する隣棟を考慮して計画する必要が あることが示唆される。一方で、 Rt 面は風向角によるばらつきはあ るものの、最も安定した負圧が作用している。4 章で示した通り、 密集住宅地において壁面には大きな正圧あるいは負圧は作用しづら く、壁面間では有効な風圧係数差を確保しづらいが、越屋根の側面 および頂部には隣棟の状況に関わらず比較的大きな正圧あるいは負 圧が作用寸ることから、壁面と越屋根との間には有効な風圧係数差 を確保することができ、換気駆動力の観点から密集住宅地において 越屋根は通風利用に有効に働くことがわかる。なお、越屋根を利用 した通風換気量の正確な把握については、小林ら5）が示す通り風圧 係数差（換気駆動力）のみでなく換気抵抗の影響を加味した越屋根 の換気特性の把握が重要となるが、本論では設計者にとって有意義 な風圧係数のデータベースの整備を目的とし、まずは隣棟の状況に より越屋根の側面および頂部に作用寸る風圧係数がいかなる影響を 受けるかを明らかにすることに主眼をおいて考察を行った。

\section{6. まとめ}

本研究では、密集住宅地においてより効率的に通風利用を図るた め、実際の住宅地を対象とした街区密度調査により密集住宅地での 平均的なグロス建蔽率を求めるとともに、得られたグロス建蔽率の 平均值を再現して行った風洞実験により下記の知見を得た。

1）グロス建蔽率と各面に作用寸る平均風圧係数には高い相関が あるため、特定のグロス建蔽率での平均風圧係数から他のグ ロス建蔽率での平均風圧係数を予測することができる。

2）モデル街区の角地に対象建物がある場合、接道面が風上側に あると他の街区形状・街区内位置の場合と異なり、壁面に正 圧が作用し通風上有利であると考えられる。また、密集した 街区モデルでは周辺模型を均等配置した場合と、モデル街区 の中央に建物が位置する場合とでは各面の平均風圧係数の風 向変化には大きな違いは見られない。

3）陸屋根より勾配屋根の方が比較的大きな負圧が作用する。ま た、寄棟屋根の場合、妻面側屋根面と平面側屋根面で大きな 風圧係数差を確保できる。

4）妻面側の隣棟条件を変更した場合、風上側の壁面に作用寸る 平均風圧係数は隣棟条件によって大きく影響を受ける。平面 側の隣棟条件を変更した場合も同様に風上側の壁面の平均風 圧係数は影響を受けるが、切妻屋根の形状により影響はやや 小さい。ただし、モデル建物を想定して各室の開口部間の最 大風圧係数差を検証すると、各面に作用する平均風圧係数よ り大きく隣棟条件の影響を受けており、設計時から周辺建物 状況を考慮した綿密な開口部の設計が重要であるといえる。

5）敷地の卓越風向および隣棟条件を正しく把握できれば、狭小 な住宅に設けた坪庭に面した開口と外部に面した開口との間 に有効な風圧係数差を確保することができ、坪庭を介した通 風経路の計画が可能である。
6）片流れ屋根の屋根面は越屋根の有無にかかわらず、概ね安定 して負圧が作用する。一方で、越屋根の側面は建物壁面と異 なり、風上側では大きな正圧が働く。また、越屋根上面は最 も大きな負圧が作用する。よって、壁面間で有効な風圧係数 差を確保しづらい密集住宅地においても、壁面と越屋根との 間には有効な風圧係数差を確保することができる。

今後も引き続き、密集住宅地を対象とした風圧係数のデータベー スの充実を図り、設計者にとって有意義な設計情報の整備を進めて いく予定である。

\section{謝辞}

本研究は、平成 19 年度科学研究費補助金 (基盤研究(B))「多様な暖 冷房方式と通風利用による快適性と省エネ性の統合的評価手法に関 する研究」(課題番号:19360256、研究代表者:東京大学教授・坂本 雄三）の助成のもと実施された。ここに記し謝意を表す。

\section{参考文献}

1) E. Maruta, T. Sawachi, T, Nakano: Study on Wind Pressure Coefficients of Detached Houses, Part 1 Rectangular and L-shaped Houses with the Gable and Hipped Roof, Summaries of Technical Papers of Annual Meeting, Architectural Institute of Japan, D- II, pp. 791-792, 2005 丸田榮藏, 澤地孝男, 中尾武史: 戸建住宅の風圧係数に関する研究 そ の 1 切妻 - 寄せ棟屋根を有する矩形と L 型平面の住宅, 日本建築学会大 会学術講演梗概集, D- II , pp. 791-792， 2005

2) M. Murakami, N. Kobayashi, S. Kato, S. Akabayashi: Experimental Study on Natural Ventilation of Dwellings (Part 1), Field Experiment with Full-scale House Model and Wind Tunnel Experiment with 1/40 Model, Journal of Architecture, Planning and Environmental Engineering (Transaction of AIJ), No. 372, pp. 10-20, 1987.2 村上周三，小林信行，加藤伸介，赤林伸一：住宅の自然通風に関する実 験的研究（その 1) 実測と風洞模型実験による天空の通風効果を中心 として, 日本建築学会計画系論文報告集, 第 372 号, pp. 10-20, 1987.2

3) S. Akabayashi, Y. Sasaki, J. Sakaguchi, Y. Tominaga: Study on of The Evaluation Method of a Cross Ventilated Buiding performance, Journal of Environmental Engineering (Transaction of AIJ), No. 568, pp. 49-56, 2003. 6

赤林伸一, 佐々木淑貴, 坂口淳, 富永禎秀: 通風性能の定量的評価手法 に関する研究, 日本建築学会環境系論文集, 第 568 号, pp. 49-56, 2003. 6

4) S. Nishizawa, T. Sawachi, E. Maruta, H. Seto, T. Kurabuchi: Wind Pressure Coefficient on Detached Houses in the Densely Built-up Area, Summaries of Technical Papers of Annual Meeting, Architectural Institute of Japan, D- II , pp. 795-796, 2005

西澤繁毅, 澤地孝男, 丸田榮藏, 倉㴊隆, 瀬戸裕直: 密集住宅地におけ る戸建住宅の風圧係数分布の検討, 日本建築学会大会学術講演梗概集, D- II , pp. 795-796， 2005

5) T. Kobayashi, T. Yamanaka, H. Kotani, K. Sagara, Y. Maruhashi, S. Tanabe: Ventilation Performance of Monitor Rof Provided for a Pitched-roof Detached House, Journal of Environmental Engineering (Transaction of AIJ), Vol.75, No.653, pp. 595-601, 2010.7 小林知宏, 山中俊夫, 甲谷寿史, 相良和伸, 丸橋靖明, 田辺慎吾: 勾配 屋根を有する独立住宅に設置された越屋根の換気特性, 日本建築学会環 境系論文集，第 75 巻，第 653 号, pp. 595-601，2010.7

6) M. Takizawa, T. Kurabuchi, D. Narumi, T. Nonaka, R. Takano: Evaluation of the Effectiveness of the Ventilation Tower Use in Comparison with the Wall Face-to-face Route, Study on Draft and Ventilation Promotion Using a Ventilation Tower in Dense Urban Areas Part 1, Journal of Environmental Engineering (Transaction of AIJ), Vol. 82, No. 731, pp. 43-50, 2017. 1 滝澤正玄, 倉㴊隆, 鳴海大典, 野中俊宏, 鷹野亮: 壁対面経路に対する 
換気塔利用の有効性に関する評価 密集市街地における換気塔を利用し た通風・換気促進に関する研究 第 1 報, 日本建築学会環境系論文集, 第 82 巻, 第 731 号, pp. 43-50, 2017. 1

7) Y. Akamine, M. Mae, K. Taniguchi, K. Takase: A Study on Cross-Ventilation-Design for Detached Residences, Part 1 Comparison between the Weather Data Measured above the Roof and AMeDAS Weather Data, Summaries of Technical Papers of Annual Meeting, Architectural Institute of Japan, D- II, pp. 757-758, 2007

赤嶺嘉彦, 前真之, 谷口景一朗, 高瀬幸造：戸建住宅における通風の設 計手法に関する研究 その 1 屋根上部における外部気象の実測結果とア メダス気象データの比較, 日本建築学会大会学術講演梗概集, D- II , pp. $757-758,2007$

8) K. Sato, E. Maruta, T. Sawachi, H. Seto, T. Kondou, A. Hoyano, Y. Kobayashi, S. Shirota, Y. Takahashi: Influence of neighboring building on Wind Tunnel Experiment, Part 1 Same Scale Building, Summaries of Technical Papers of Annual Meeting, Architectural Institute of Japan, D- II, pp. 689-690, 2002

佐藤健一, 澤地孝男, 瀬戸裕直, 丸田榮藏, 近藤武士, 梅干野晃, 小林 康之, 城田修司, 高橋泰雄：隣接建物がある場合の風圧に関する風道実 験 その 1 中層建物に対する隣接建物（中層建物）までの距離の違いの 影響, 日本建築学会大会学術講演梗概集, D- II , pp. 689-690, 2002

9) Architectural Institute of Japan: Recommendations for Loads on Buildings, 2015 日本建築学会編：建築物荷重指針・同解説，2015

10) H. Hoshino, Y. Akamine, M. Kamata, M. Imano, Y. Sakamoto: Cross-Ventilation in Highly Populated Residential Areas, Part 3 Air Flow Path in Void Space of Detached House, Summaries of Technical Papers of Annual Meeting, Architectural Institute of Japan, D- II , pp. 495-496, 2008

星野秀明, 赤嶺嘉彦, 鎌田元康, 今野雅, 坂本雄三：密集市街地におけ る通風有効利用に関する研究（第 3 報）通風時におけるボイド内気流 風向の把握, 日本建築学会大会学術講演梗概集, D- II, pp. 495-496, 2008

11) K. Taniguchi, M. Mae, Y. Akamine, T. Takase: A Study on the Cross-Ventilation-Design for Detached Residences, Part 2 Actual Measurement of Flow Pattern in Cross-Ventilated-Houses, Summaries of Technical Papers of Annual Meeting, Architectural Institute of Japan, D- II , pp. 759-760, 2007

谷口景一朗, 前真之, 赤嶺嘉彦, 高瀬幸造：戸建住宅における通風の設 計手法に関する研究 その 2 実測による建物開口部における通風気流性 状の把握, 日本建築学会大会学術講演梗概集, D- II , pp. 759-760, 2007 
WIND PRESSURE COEFFICIENT DISTRIBUTION

OF DETACHED HOUSES IN A DENSE RESIDENTIAL BLOCK

\author{
Keiichiro TANIGUCHI ${ }^{* 1}$ and Yoshihiko AKAMINE ${ }^{* 2}$ \\ ${ }^{* 1}$ Project Assist. Prof., Graduate School of Eng., The Univ. of Tokyo, M.Eng. \\ ${ }^{* 2}$ Senior Researcher, Housing Dept., National Institute for Land and Infrastructure Management, Dr.Eng.
}

This study aimed to establish a handy database of wind pressure coefficients that can assist designing buildings with better cross ventilation in a dense residential block. With this in mind, we started by surveying the blocks density of the main residential areas in Tokyo and calculated their average Gross Building Coverage Ratio (Gross $\mathrm{BCR}$ ). It was found that almost all Gross BCR is in the range of $24 \%$ to $42 \%$, and the average is approximately $33 \%$. Hence, the Gross BCR of $33 \%$ was used to build the context model of the wind tunnel test whereas various experiments on the wind pressure acting on the wall/roof surface of the building under different conditions were made. Ultimately, the study deduced the following points:

1) A high correlation was found between the Gross BCR and the average wind pressure coefficient acting on each surface. Therefore, it is possible to predict the average wind pressure coefficient for any Gross BCR with good accuracy.

2) When the target building is located at the corner of the real context block, and when the facing-the-street surface is on the windward side, a positive pressure is expected to act on these surfaces, which is advantageous for ventilation, unlike other setups. On another hand, when the building of interest is at the center of the dense blocks, the change in the wind direction has an intangible effect on the average wind pressure coefficient on the surfaces when comparing between the case where the surrounding buildings are simplified dense context and the case when the building is located center of the real context block.

3) A sloped roof has a relatively higher negative pressure relative to a flat roof. Meanwhile, for the hipped roof, a great wind pressure coefficient differences can be somewhat ensured between the gable end side and the eaves side surfaces.

4) It was found that changing the neighbor building condition facing the gable wall has a profound effect on the average wind pressure coefficient acting on that wall. Meanwhile, much less effect on the eave wall is found when the neighbor building, that faces the eave side, is manipulated. Yet, in both setups (either gable or eave-facing adjacencies) manipulating the neighbor building significantly change the pressure difference between the windows on a corner room, considering that one window is at the gable wall and the other eave wall. Accordingly, it can be said that it is important to design the opening carefully and seriously consider the surrounding buildings in the design phase. Designers should not only look at the pressure coefficient of each wall separately, but identifying the potentials of the pressure differences between the various walls.

5) The stable negative pressure generating strategies can be well developed if the site prevailing wind direction and the neighbor building conditions can be obtained correctly. Such strategy can act and compensate, the courtyard in a narrow housing as an effective ventilation path between the outside wall.

6) The negative pressure on the shed roof is quite stable, regardless of the presence of the roof monitor. The wind pressure coeffect acting on the monitor sides is always greater than acting on walls, for all wind directions. In fact, the highest negative pressure is found on the top of the roof monitor and it has the greatest potential for driving natural ventilation. Therefore, the prevailing wind direction should be carefully identified when planning an opening in roof monitor as its position will dictate either the monitor is going to be an inlet or an outlet for the cross ventilation. 